\title{
Amniotic Fluid-Derived Mesenchymal Stem Cells Cut Short the Acuteness of Cisplatin-Induced Nephrotoxicity in Sprague-Dawley Rats
}

Fatma Al-Husseiny ${ }^{1,5}$, Mohamed Ahmed Sobh ${ }^{2}$, Rehab H. Ashour ${ }^{4}$, Samah Foud ${ }^{5}$, Tarek Medhat ${ }^{3}$, Abdel-Hady El-Gilany, ${ }^{6}$ Doaa Elghannam, Hassan Abdel-Ghaffar ${ }^{7}$, Mohamed-Ahdy Saad ${ }^{4,5}$, Mohamed Sobh ${ }^{3,5}$

\author{
${ }^{1}$ Department of Pathology, ${ }^{2}$ Zoology Unit- ${ }^{3}$ Urology and Nephrology Center, ${ }^{4}$ Department of Clinical Pharmacology, \\ ${ }^{5}$ Medical Experimental Research Center (MERC), ${ }^{6}$ Department of Public Health, \\ ${ }^{7}$ Department of Clinical Pathology, Faculty of Medicine, Mansoura University, Mansoura, Egypt
}

Background and objectives: Cisplatin is a nephrotoxic chemotherapeutic agent. So, preventive measures worth to be evaluated. Human amniotic fluid stem cells (hAFSCs) in prevention or amelioration of cisplatin-induced acute kidney injury (AKI) in Sprague-Dawley rates have been tested.

Methods: 80 Sprague-Dawley rats $(250 \sim 300 \mathrm{~g})$ were used and divided into 4 major groups, 20 rats each. Group I: Saline-injected group. Group II: Cisplatin-injected group ( $5 \mathrm{mg} / \mathrm{kg}$ I.P). Group III: Cisplatin-injected and hAFSCs-treated group $\left(5 \times 10^{6}\right.$ hAFSCs I.V. one day after cisplatin administration). Group IV: Cisplatin-injected and culture media-treated group. Each major group was further divided into 4 equal subgroups according to the timing of sacrifice; 4, 7, 11 and 30 days post-cisplatin injection. Renal function tests were done. Kidney tissue homogenate oxidative stress parameters malondialdehyde (MDA), superoxide dismutase (SOD) and glutathione (GSH) were determined. Histopathological scoring systems for active injury, regenerative and chronic changes were analyzed separately. Results: hAFSCs characterization and differentiation was proved. Cisplatin injection resulted in a significant increase in serum creatinine and $\mathrm{MDA}$ and decrease in SOD, GSH and creatinine clearance. These changes were attenuated early by day 4 with the use of hAFSCs. Cisplatin injection induced tubular necrosis, atrophy, inflammatory cells infiltration and fibrosis. The use of hAFSCs was associated with significantly lowered injury score at day 4, 7, 11 and 30 with marked regenerative changes starting from day 4.

Conclusion: hAFSCs have both a protective and regenerative activities largely through an antioxidant activity. This activity cut short the acuteness of cisplatin nephrotoxicity.

Keywords: Cisplatin, nephrotoxicity, Human amniotic fluid Stem cells, Oxidative stress

Accepted for publication February 11, 2016, Published online May 30, 2016 Correspondence to Rehab H. Ashour

Lecturer of Clinical Pharmacology, Faculty of Medicine, Mansoura University, El-Gomhoria Street, El-Mansoura 35516, Egypt Tel: +2-01005409956, Fax: +20-50-2248203

E-mail: zohoor26203@yahoo.com,drrehab40@mans.edu.eg

(c) This is an open-access article distributed under the terms of the Creative Commons Attribution Non-Commercial License (http://creativecommons.org/ licenses/by-nc/4.0/), which permits unrestricted non-commercial use, distribution, and reproduction in any medium, provided the original work is properly cited.

\section{Introduction}

Acute kidney injury (AKI) is a serious clinical condition associated with high morbidity and mortality. It refers to a clinical syndrome characterized by a rapid decrease in renal excretory function, with the accumulation of nitrogenous end-products such as creatinine and urea (1). Drugs seem to contribute to AKI in about $20 \%$ of patients, especially in critically ill patients (2). Cisplatin is a potent chemotherapeutic agent with evident nephrotoxicity. Several mechanisms have been proposed for cisplatin-induced nephrotoxicity including direct toxicity to renal 
tubular epithelial cells (3), apoptosis (4), activation of the mitogen-activated protein kinase (MAPK)-signaling pathway (5), oxidative stress (6), and inflammation (7).

Based on these different mechanisms, numerous renoprotective approaches have been developed; however, the offered renoprotection is mostly partial and combination strategies may be better (8). Stem cell-based therapy is a new promising therapeutic approach for organ repair (9). Several groups successfully demonstrated the use of different stem cell types in the treatment of AKI in different experimental animal models. Most of these studies focused on bone marrow-derived stem cells (BMSCs) and in vitro expanded MSCs (10).

Human amniotic fluid is a new promising source of stem cell (hAFSCs) with high plasticity and their subsequent differentiation into the three types of germ layer cells (11). In this context, the use of hAFSCs is considered ethically acceptable compared to embryonic stem cells as it is easily available without destruction of human embryo (12). Moreover, hAFSCs lack teratoma formation when injected in vivo (13).

The novelty of this study originates from the long term 30 days follow up of the cisplatin-induced renal oxidative stress studying the probable anti-oxidant activity of hAFSCs. In addition, the assessment of renal histolopathologic changes has been conducted using a new histopathology scoring system that includes different features of injury, regeneration and chronicity separately.

\section{Aim of work}

This work aims to investigate the possible renoprotective effect of hAFSCs on cisplatin-induced acute kidney injury in Sprague-Dawley rats.

\section{Materials and Methods}

The study design and protocol was revised and approved by Mansoura Medical Research Ethics committee.

\section{Agents}

Cisplatin obtained from David Bull Laboratories, Dulbecco's modified Eagle's medium (DMEM) containing 20\% fetal bovine serum (FBS) obtained from Invitrogen (Invitrogen, Carlsbad, CA, USA).

\section{Harvest and Culture of human amniotic fluid stem cells (hAFSCs)}

Mesenchymal stem cells were isolated from the human amniotic fluid (AF) of 15 women who underwent a cesarean delivery for breech presentation after having their consent according to the instruction of ethical committee of the faculty of medicine of Mansoura University. The mean \pm SD pregnancy duration (fetal age +2 weeks) was $38 \pm 1$ weeks and the mean volume of the AF samples was $11.2 \pm 4.7 \mathrm{~mL}$.

Samples were collected by puncturing the membranes after the uterine muscle was opened for the cesarean delivery. Cells were isolated from the AF samples no more than 4 hours prior to use. Samples were centrifuged at $1100 \mathrm{rpm}$ for 5 minutes and all the isolated cells were plated in six 35-mm Petri dishes containing low-glucose Dubelco modified Eagle's medium (DMEM) (Invitrogen, Carlsbad, CA, USA) supplemented with $100 \mathrm{U} / \mathrm{mL}$ of penicillin, $0.1 \mathrm{mg} / \mathrm{mL}$ of streptomycin, $10 \mathrm{ng} / \mathrm{mL}$ of basic fibroblast growth factor, $10 \mathrm{ng} / \mathrm{mL}$ of epidermal growth factor (all from Peprotech, Rocky Hill, NJ, USA), and 20\% of fetal bovine serum (Invitrogen). The medium was renewed after incubation of the cells at $37^{\circ} \mathrm{C}$ with $5 \%$ humidified carbon dioxide for 7 days and the non-adhering $\mathrm{AF}$ cells were removed.

The medium was replaced twice weekly until the cells reached $70 \%$ confluence, then they were treated with $0.25 \%$ trypsin and $1 \mathrm{mM}$ EDTA (Invitrogen) for 3 minutes. The released MSCs were collected and replated in a split ratio of 1:3 under the same culture conditions. Cells were used for experiments after the $3^{\text {rd }}$ passage.

\section{In-vitro Differentiation Potential Assay}

To assess their osteogenic, adipogenic, and chondrogenic differentiation potential, AF-derived adherent cells were grown until confluence, and the growth medium was replaced with the inductive medium consisting of Iscove's modified Dulbecco's medium (Invitrogen), 20\% FCS, 100 $\mathrm{U} / \mathrm{ml}$ penicillin, $100 \mu \mathrm{g} / \mathrm{ml}$ streptomycin, and $0.05 \mathrm{mM}$ $\beta$-mercaptoethanol supplemented with specific differentiation reagents as follows:

Osteogenesis assay: Cultures were fed twice a week for 3 weeks with $10 \mathrm{mM} \beta$-glycerophosphate, $50 \mu \mathrm{g} / \mathrm{ml}$ ascorbic acid 2-phosphates, and $10^{-9} \mathrm{M}$ dexamethasone (14). Then cells were fixed with $10 \%$ formalin for $20 \mathrm{~min}$ at room temperature and mineralization (presence of calcium-rich hydroxyapatite) of the extracellular matrix was assessed by staining for $20 \mathrm{~min}$ with $2 \% \mathrm{wt} / \mathrm{vol}$ Alizarin Red S, adjusted to $\mathrm{pH} 4.1$ with ammonium hydroxide. All reagents were from Sigma (Sigma Chemical Co., St. Louis, MO, USA) (15).

Adipogenesis assay: Cells were incubated for 3 weeks with $5 \mu \mathrm{g} / \mathrm{ml}$ insulin (Sigma) and $10^{-9} \mathrm{M}$ dexamethasone. Adipogenic differentiation was visualized in phase-contrast microscopy by the presence of highly refractive intra- 
cellular lipid vacuoles (14) Oil Red O (Sigma) staining was used to assay the accumulation of lipid droplets in these vacuoles (15).

Chondrogenesis assay: $6 \times 10^{5}$ cells were centrifuged to form a pellet on the bottom of a $15-\mathrm{ml}$ polypropylene tube (Falcon). The micromass was cultured in $500 \mu 1$ of chondrogenic medium that consisted of $50 \mu \mathrm{g} / \mathrm{ml}$ ascorbic acid 2-phosphate and $1 \mathrm{ng} / \mathrm{ml}$ TGF- $\beta 1$ (Sigma) (14). After 3 weeks of culture, cell clumps were harvested, embedded in paraffin, cut into $3-\mu \mathrm{m}$ sections, and stained for glycosaminoglycans using $0.1 \%$ safranin O (Sigma).

\section{Flow cytometry for cell surface expression assay}

The AF-derived stem cells at passage 3 were released by trypsinization and analyzed by fluorescence-activated cell sorting (FACS) analysis. The cells were centrifuged at $1200 \mathrm{rpm}$ for 5 minutes, and then solved in phosphate buffered saline (PBS) at the concentration of $\left(1 \times 10^{6} / \mathrm{ml}\right)$. The cells were stained with different fluorescently labeled monoclonal antibodies (mAb) according to Perin et al. The fluorescent labeled directed antibodies CD34, CD14, CD29, CD90, CD13, CD105 and Oct4 (10 $\mu 1$ for each sample) were added and incubated for 30 minutes at room temperature. Labeled cells were thoroughly washed with two volumes of PBS and fixed in flow buffer ( $1 \%$ formaldehyde in PBS). The labeled cells were analyzed on a FACS Caliber (Becton-Dickinson, Franklin Lakes, NJ, USA) by collecting 10000 events with the Cell Quest software program (Becton-Dickinson, Franklin Lakes, NJ, USA) (13).

\section{Real-Time Quantitative PCR}

Total RNA was isolated from MSC, and real-time RTPCR was performed as described previously (16). The amplified DNA fragments were visualized through 2\% agarose gel electrophoreses and photographed under UV light. The adipogenic genes used were adiponectin and adipocyte lipid-binding protein (ALBP); in addition, osteocalcin gene was used for osteogenic differentiation; gelyceraldehyde-3-phosphate dehydrogenase (GAPDH) was used as an internal standard. The primer sequences were as follow: for adiponectin, the forward primer was 5'-TCCTGCCAGTAACAGGGAAG-3' and the reverse primer was 5'-GGTTGGCGATTACCCGTTTG-3'; for ALBP, the forward primer was 5'-TACCTGGAAACTTGTCTCCAGTGAA-3' and the reverse primer was 5'-CCATTTCTGCACATGTACCAGGACA-3'; for osteocalcin, the forward primer was 5'-ACACTCCTCGCCCTATTG-3' and the reverse primer was 5'-GATGTGGTCAGCCAACTC-3'; for GAPDH, the forward primer was 5'-ACAAGATGGTGAAGGT-
CGGTG-3' and the reverse primer was 5'-AGAAGGCAGCCCTGGTAACC-3'.

\section{Animals and Experimental Design}

Rats were kept on a regular $12 \mathrm{~h}$ dark/light cycle with free access to standard rat chow and tap water ad libitum. Eighty inbred female Sprague-Dawley rats (8 weeks old, weighing 180 to $210 \mathrm{~g}$ ) from Medical Experimental Research Center (MERC), Mansoura Faculty of Medicine were used and divided into the following groups:

Group I $(n=20)$ : (negative control) was injected with $1 \mathrm{ml}$ normal saline alone (I.P). Group II $(\mathrm{n}=20)$ : (cisplatin 'CDDP'-treated group) was injected with a single dose of cisplatin $(5 \mathrm{mg} / \mathrm{kg} \mathrm{I.P)}$ in $1 \mathrm{ml}$ saline as described previously (17). Group III $(\mathrm{n}=20)$ : (cisplatin and human amniotic fluid stem cells-treated group) this group was injected with $0.5 \mathrm{ml}$ of culture media containing $5 \times 10^{6}$ MSCs into the tail vein. Group VI $(n=20)$ : (cisplatin and DMEM culture media-treated group) this group was injected with $0.5 \mathrm{ml}$ culture media into the tail vein (I.V).

On day one after kidney disease induction, groups II received stem cell suspended in fresh culture media; while, group VI injected with fresh culture media alone. Five rats were killed at different time intervals in all groups at days 4, 7, 11, and 30 for obtaining kidney tissue and blood samples.

\section{Biochemical Measurements}

The following parameters were determined with the use of commercially available kits: serum and urinary creatinine (Diamond diagnostics, Jaffe. Colorimetric - kinetic, Hannover, Germany) and blood urea nitrogen (BUN) using urea kits, Berthelot enzymatic colorimetric method (Diamond Diagnostics Company, Hannover, Germany) according to manufacture instruction.

Lipid peroxidation (malondialdehyde 'MDA' production) and reduced glutathione (GSH) contents and superoxide dismutase activity (SOD) in the kidney tissue were determined according to the methods of (18) and (19), respectively.

\section{Renal Morphology}

The left kidney was per fused in a retrograde fashion through the abdominal aorta using saline $0.9 \%$ till complete clearance of the perfusion fluid, and then $10 \%$ neutral buffered formalin for in situ fixation. Renal samples were coded and processed for light microscopic observation. Histopathological changes were analyzed in the different regions of the kidney (cortex, outer strip of outer medulla "OSOM", inner strip of outer medulla "ISOM", and inner 
medulla hematoxylin and eosin (H\&E) according to a new scoring system (submitted for publication):

Active injury changes: These include necrotic tubules and interstitial infiltration by inflammatory cells. Necrotic tubules were scored according to the number of necrotic tubules counted/high power field (HPF) and scored to 1, 2, 3 and 4 according to $1 \sim 3,4 \sim 5,6 \sim 10$ and $>10$ necrotic tubules / HPF. The inflammatory cells were scored as 1, 2, 3 corresponding to mild, moderate \& severe. The maximum score of active injury is 7 .

Regenerative changes: These include presence of mitosis, solid cellular sheets between the tubules, intraluminal cellular proliferation forming solid tubules, tubules lined with large vesicular nuclei, and tubules lined by cells having hyper chromatic prominent nuclei and little cytoplasm giving the luminal border a festooned appearance. Each of solid cellular sheets and Solid tubules counted as $1 \sim 2,3 \sim 5$ and $>5 / \mathrm{HPF}$ are scored as 1, 2 and 3 respectively. Mitosis is scored as 1, 2 and 3 corresponding to $1 \sim 2,3 \sim 5$ and $>5 / 10 \mathrm{HPF}$. While tubules with large vesicular nuclei and tubules with basophilic prominent nuclei get score 1 when present and get score zero if absent. The maximum score of regeneration is 11 .

Chronic changes: These include atrophic tubules with flat lining, casts, and thick basement membrane and interstitial fibrosis. The maximum chronicity score is 7; where the number of atrophic tubules $/ \mathrm{HPF}$ of $1 \sim 5,6 \sim 10$ and $>10$ are scored 1, 2 and 3 respectively. And the percentages of interstitial fibrosis / HPF of 25, 25 50, 50 75 and more than $75 \%$ get scores of $1,2,3$ and 4 respectively.

\section{Statistical analysis}

All analyses were conducted using SPSS (version 16.0, SPSS, IL, USA). The biochemical data were tested for Gaussian distributions by Kolmogorov-Smirnov test. For the survival rate, the significance was computed with a log-rank test. Descriptive statistics were reported as mean \pm standard deviation (SD) for continuous variables or median (min-max) for categorical variables. Differences in continuous variables were analyzed by one-way analysis of variance (ANOVA) followed by posthoc multiple comparisons (Scheffé test). Categorical variables were analyzed by Kruskal-Wallis H (K-W) followed by MannWhitney's tests. $\mathrm{p}$ value $<0.05$ was considered statistically significant at confidence interval $95 \%$.

\section{Results}

Isolation, purification and Characterization of hAFSCs hAFSCs were characterized on the basis of their pheno- type, adherence property, and their differentiating capabilities. Cells were purified in culture media with different passages and MSCs were morphologically defined by a fibroblast-like appearance. Using appropriate differentiation media, we were able to differentiate hAFSCs into osteocytes, adipocytes, and chondrocytes. hAFSCs showed calcium-rich hydroxyapatite that appeared as irregular red-orange with Alizarin red and highly refractive intracellular lipid vacuoles and droplets appear as cherry red spheres within the cells by Oil Red O staining after adipogenic induction. Chondrogenic differentiation was demonstrated by formation glycosaminoglycans with red color (Supplementary Fig. 1).

\section{Flow cytometry for cell surface expression assay}

The analyses revealed that the expression of surface antigens of MSCs derived from human amniotic fluid were negative for CD14 (11.3\%) and CD34 (15\%) while they were positive for CD29 (50\%), CD 90 (79.1\%), CD 105 (79.5\%), CD13 (36.5\%) and Oct4 (31.4\%) (Supplementary Fig. 2).

\section{Real-Time Quantitative PCR \& Gel electrophoresis}

Human amniotic fluid MSCs in adipogenic culture conditions expressed adiponectin and adipocyte lipid-binding protein (ALBP) and in osteogenic culture conditions expressed osteocalcin at different time intervals, after 4 days, 7 days, 14 days and 21 days (Supplementary Fig. 3).

\section{Effect of hAFSCs on cisplatin-induced renal dysfunction}

Sprague-Dawley rats injected with cisplatin developed impairment of renal function characterized by high serum levels of creatinine and BUN starting at $4^{\text {th }}$ days post-injection and maintained elevated until the end of the study (Table 1). Injection of hAFS cell led to significant decrease $(p<0.001)$ of serum creatinine and BUN levels at $4^{\text {th }}$ day compared with cisplatin- and DMEM culture media-treated rats (Table 1).

\section{Effect of hAFSCs on cisplatin-induced oxidative stress}

Injection of hAFS cell led to significant decrease $(p<0.001)$ of renal tissue MDA level with significant increase of renal tissue GSH and SOD levels starting from the $4^{\text {th }}$ day till the end of the study compared with cisplatin- and DMEM culture media-treated rats (Table 2).

\section{Effect of hAFSCs on cisplatin-induced renal structural injury}

Active injury changes: Pathological evaluation of the 
kidneys of cisplatin- and culture media- injected rats on day 4 showed marked degenerative changes in the form of tubular cell vacuolar degeneration, up to complete tubular necrosis and shedding of tubular cells mainly in outer strip outer medulla (OSOM). Rats treated with hAFSCs showed significant reduction $(\mathrm{p}<0.001)$ of active injury score compared to untreated controls at each time point (Table 3, Fig. 1).

Regenerative changes: Kidney sections obtained from cisplatin-injected rats treated with hAFSCs and scarified at the $4^{\text {th }}$ day showed evidence of regeneration (mitotic Figures) with significant increase of regeneration score $(\mathrm{p}<0.001)$ compared to cisplatin- and culture media- injected rats. On the $7^{\text {th }}$ day onward, the regenerative changes of hAFSCs-treated rats included solid sheets and solid regenerating tubules with significant increase of regeneration score $(\mathrm{p}<0.001)$ compared to cisplatin- and culture media- injected rats (Table 3).

Chronic changes: Rats treated with hAFSCs showed significant reduction $(\mathrm{p}<0.001)$ of chronicity score com-

Table 1. Effect of hAFSCs on biochemical measurements ( $n=20 /$ group)

\begin{tabular}{|c|c|c|c|c|c|}
\hline & & $\begin{array}{c}\text { Group I } \\
\text { negative control }\end{array}$ & $\begin{array}{c}\text { Group II } \\
\text { cisplatin-treated }\end{array}$ & $\begin{array}{c}\text { Group III } \\
\text { cisplatin }+ \text { hAFSCs-treated }\end{array}$ & $\begin{array}{c}\text { Group VI } \\
\text { Cisplatin + DMEM } \\
\text { culture media treated }\end{array}$ \\
\hline \multirow{4}{*}{$\begin{array}{l}\text { Sr.Cr. } \\
\text { (mg/dl) }\end{array}$} & Day 4 & $0.40 \pm 0.12$ & $1.92 \pm 0.03 *$ & $1.02 \pm 0.08^{* \S}$ & $1.88 \pm 0.1^{* \#}$ \\
\hline & Day 7 & $0.37 \pm 0.12$ & $1.61 \pm 0.05^{*, \neq}$ & $0.85 \pm 0.08^{* \S, \ddagger}$ & $1.63 \pm 0.03 * \#, \neq$ \\
\hline & Day 11 & $0.41 \pm 0.11$ & $1.00 \pm 0.07^{*}, \neq, \dagger$ & $0.70 \pm 0.06^{* \S, ~}$ & $1.02 \pm 0.1^{*, \#, \ddagger, \dagger}$ \\
\hline & Day 30 & $0.39 \pm 0.10$ & 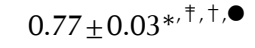 & $0.85 \pm 0.05^{* \S, \ddagger}$ & $0.81 \pm 0.04 * \|, キ, \dagger, \bullet$ \\
\hline \multirow{4}{*}{$\begin{array}{l}\text { BUN } \\
(\mathrm{mg} / \mathrm{dl})\end{array}$} & Day 4 & $18.6 \pm 1.14$ & $85.6 \pm 1.67^{*}$ & $34.4 \pm 1.14^{*, \S}$ & $85.4 \pm 1.14^{*, \#}$ \\
\hline & Day 7 & $18.2 \pm 1.48$ & $55.2 \pm 1.30^{*}, \neq$ & $28.0 \pm 1.22^{*,, ~}$ & $53.8 \pm 0.84^{*, \#, \neq}$ \\
\hline & Day 11 & $17.2 \pm 1.48$ & $32.3 \pm 1.48^{*, \uparrow, \dagger}$ & $24.4 \pm 0.89^{*, s, \ddagger, \dagger}$ & $32.4 \pm 1.51^{*, \#, \uparrow, \dagger}$ \\
\hline & Day 30 & $18.0 \pm 1.58$ & $26.4 \pm 0.55^{*, キ, \dagger, \bullet}$ & $23.2 \pm 0.84^{*, \S, \ddagger}$ & $26.2 \pm 0.83 * \| \#, \neq, \dagger, \bullet$ \\
\hline \multirow{4}{*}{$\begin{array}{l}\text { Cr. Cl. } \\
(\mathrm{ml} / \mathrm{min} / \\
100 \mathrm{gm})\end{array}$} & Day 4 & $1.62 \pm 0.44$ & $0.007 \pm 0.001 *$ & $0.018 \pm 0.06^{*}$ & $0.008 \pm 0.001^{*}, \mp$ \\
\hline & Day 7 & $1.78 \pm 0.55$ & $0.014 \pm 0.001^{*, \ddagger}$ & $0.045 \pm 0.001^{*, \S, \mp}$ & $0.012 \pm 0.002 *, \#, \neq$ \\
\hline & Day 11 & $1.86 \pm 0.56$ & $0.050 \pm 0.01^{*, \uparrow, \dagger}$ & $0.060 \pm 0.007^{*, \neq, \dagger}$ & $0.050 \pm 0.013^{*, \uparrow, \dagger}$ \\
\hline & Day 30 & $1.76 \pm 0.55$ & $0.360 \pm 0.17^{*, キ, 十 \bullet}$ & $1.000 \pm 0.14^{*, s, \ddagger, 十, \bullet}$ & $0.460 \pm 0.26^{*, キ, 十 \bullet}$ \\
\hline
\end{tabular}

Significant difference compared to corresponding * ${ }^{*}$ control, ${ }^{\S}$ cisplatin group and ${ }^{*}$ cisplatin + hAFSCs group. Significant difference compared to intragroup ${ }^{\ddagger}$ day $4,{ }^{\dagger}$ day $7, \bullet^{\bullet}$ day 11 by one-way analysis of variance (ANOVA) followed by posthoc multiple comparisons (Scheffé test) at $\mathrm{p} \leq 0.05$.

Table 2. Effect of hAFSCs on renal tissue oxidative stress parameters $(n=20 /$ group $)$

\begin{tabular}{|c|c|c|c|c|c|}
\hline & & $\begin{array}{c}\text { Group I } \\
\text { negative control }\end{array}$ & $\begin{array}{c}\text { Group II } \\
\text { cisplatin-treated }\end{array}$ & $\begin{array}{c}\text { Group III } \\
\text { cisplatin }+ \text { hAFSCs-treated }\end{array}$ & $\begin{array}{c}\text { Group VI } \\
\text { Cisplatin + DMEM } \\
\text { culture media treated }\end{array}$ \\
\hline MDA & Day 4 & $14.6 \pm 1.61$ & $66.5 \pm 2.83^{*}$ & $34.7 \pm 6.72^{* \S}$ & $66.6 \pm 2.68^{*, \#}$ \\
\hline \multirow{3}{*}{ (nmol/g tissue) } & Day 7 & $14.9 \pm 1.50$ & $64.9 \pm 3.93^{*,}$ & $26.1 \pm 2.13^{*,, \mp}$ & $66.9 \pm 2.29^{*, \#}$ \\
\hline & Day 11 & $15.4 \pm 1.63$ & $35.5 \pm 3.33^{*, \uparrow, \dagger}$ & $17.8 \pm 1.78^{\S, \uparrow, \dagger}$ & $34.8 \pm 2.84^{*, \#, \neq, \dagger}$ \\
\hline & Day 30 & $15.1 \pm 1.62$ & $30.1 \pm 4.61^{*, \uparrow, \dagger}$ & $17.6 \pm 2.29^{\S, \uparrow, \dagger}$ & $28.1 \pm 1.58^{*, \#, キ, \dagger, \bullet}$ \\
\hline $\mathrm{GSH}$ & Day 4 & $5.40 \pm 0.25$ & $0.26 \pm 0.03 *$ & $0.76 \pm 0.02^{* \S}$ & $0.26 \pm 0.02 *, \#$ \\
\hline \multirow[t]{3}{*}{ (mmol/g tissue) } & Day 7 & $5.44 \pm 0.23$ & $0.54 \pm 0.03^{*,}$ & $2.64 \pm 0.36^{*, s, \mp}$ & $0.52 \pm 0.03^{* \#, \neq}$ \\
\hline & Day 11 & $5.55 \pm 0.17$ & $1.49 \pm 0.33^{*, \uparrow, \dagger}$ & $3.55 \pm 0.15^{*,, \uparrow, \dagger}$ & $1.32 \pm 0.30^{* \#, \neq, \dagger}$ \\
\hline & Day 30 & $5.32 \pm 0.31$ & $1.92 \pm 0.03^{*, \uparrow, \dagger}$ & $3.98 \pm 0.43^{*, \S, \neq, \dagger}$ & $1.91 \pm 0.05^{*, \#, \neq, \dagger, \bullet}$ \\
\hline SOD & Day 4 & $20.36 \pm 1.70$ & $2.98 \pm 0.19 *$ & $6.93 \pm 0.42^{*, s}$ & $2.94 \pm 0.23^{* \#}$ \\
\hline \multirow[t]{3}{*}{ (U/g tissue) } & Day 7 & $19.92 \pm 1.39$ & $6.24 \pm 0.42^{*, \ddagger}$ & $10.69 \pm 0.33^{*, \varsigma, \neq}$ & $6.22 \pm 0.45^{* \#, \neq}$ \\
\hline & Day 11 & $19.88 \pm 1.40$ & $9.98 \pm 0.32^{*, \ddagger} \dagger$ & $15.73 \pm 0.29 *, \S, \uparrow, \dagger$ & $10.0 \pm 0.25^{*, \#, \neq, \dagger}$ \\
\hline & Day 30 & $20.22 \pm 1.70$ & $15.3 \pm 0.36^{*, \neq, 十, \bullet}$ & $18.74 \pm 0.15^{\S, \ddagger, 十, \bullet}$ & $15.6 \pm 0.49^{*, \#, キ, 十 \bullet}$ \\
\hline
\end{tabular}

Significant difference compared to corresponding ${ }^{*}$ control, ${ }^{\S}$ cisplatin group and ${ }^{\#}$ cisplatin + hAFSCs group.

Significant difference compared to intragroup ${ }^{\ddagger}$ day $4,{ }^{\dagger}$ day $7, \bullet^{\bullet}$ day 11 by one-way analysis of variance (ANOVA) followed by posthoc multiple comparisons (Scheffé test) at $\mathrm{p} \leq 0.05$. 
Table 3. Active injury score, Regeneration score, and Chronicity score in OSOM of different experimental groups ( $\mathrm{n}=20$ )

\begin{tabular}{|c|c|c|c|c|c|}
\hline & & $\begin{array}{c}\text { Group I } \\
\text { negative control }\end{array}$ & $\begin{array}{c}\text { Group II } \\
\text { cisplatin-treated }\end{array}$ & $\begin{array}{c}\text { Group III } \\
\text { cisplatin + hAFSCs-treated }\end{array}$ & $\begin{array}{c}\text { Group VI } \\
\text { Cisplatin + DMEM } \\
\text { culture media treated }\end{array}$ \\
\hline \multirow[t]{4}{*}{ Active injury score } & Day 4 & $0.0(0.0 \sim 0.0)$ & $7.0(7.0 \sim 7.0)^{*}$ & $3.0(2.0 \sim 3.0)^{*, \S}$ & $6.0(6.0 \sim 7.0)^{*, \#}$ \\
\hline & Day 7 & $0.0(0.0 \sim 0.0)$ & $6.0(6.0 \sim 6.0)^{*}$ & $3.0(2.0 \sim 3.0)^{*, \S}$ & $6.0(6.0 \sim 6.0)^{*, \#}$ \\
\hline & Day 11 & $0.0(0.0 \sim 0.0)$ & $4.0(4.0 \sim 4.0)^{*, \neq}$ & $1.0(1.0 \sim 1.0)^{*, \$, ~}$ & $6.0(5.0 \sim 6.0)^{*, \#}$ \\
\hline & Day 30 & $0.0(0.0 \sim 0.0)$ & $4.0(4.0 \sim 4.0)^{*, \neq}$ & $1.0(1.0 \sim 1.0)^{*, \S, \ddagger}$ & $3.0(3.0 \sim 3.0)^{*, \#, キ, \bullet}$ \\
\hline \multirow[t]{4}{*}{ Regeneration score } & Day 4 & $0.0(0.0 \sim 0.0)$ & $0.0(0.0 \sim 0.0)$ & $4.0(3.0 \sim 5.0)^{*, \S}$ & $0.0(0.0 \sim 0.0)^{\#}$ \\
\hline & Day 7 & $0.0(0.0 \sim 0.0)$ & $0.0(0.0 \sim 0.0)$ & $7.0(6.0 \sim 7.0)^{*, \S}$ & $0.0(0.0 \sim 0.0)^{\#}$ \\
\hline & Day 11 & $0.0(0.0 \sim 0.0)$ & $1.0(1.0 \sim 2.0)^{*, \neq}$ & $8.0(8.0 \sim 8.0)^{*, \S, \ddagger}$ & $1.0(1.0 \sim 2.0)^{*, \#, \neq}$ \\
\hline & Day 30 & $0.0(0.0 \sim 0.0)$ & $3.0(3.0 \sim 3.0)^{*, \neq, \bullet}$ & $8.0(7.0 \sim 9.0)^{*, \S, \neq}$ & $3.0(3.0-3.0)^{*}, \#, \neq, \bullet$ \\
\hline \multirow[t]{4}{*}{ Chronicity score } & Day 4 & $0.0(0.0 \sim 0.0)$ & $3.0(3.0 \sim 3.0)^{*}$ & $2.0(2.0 \sim 2.0)^{*, \S}$ & $3.0(3.0 \sim 3.0)^{*, \#}$ \\
\hline & Day 7 & $0.0(0.0 \sim 0.0)$ & $4.0(4.0 \sim 4.0)^{*}$ & $2.0(2.0 \sim 2.0)^{*, \S}$ & $4.0(4.0 \sim 5.0)^{*, \#}$ \\
\hline & Day 11 & $0.0(0.0 \sim 0.0)$ & $5.0(5.0 \sim 5.0)^{*}, \neq$ & $2.0(2.0 \sim 2.0)^{*, \S}$ & $5.0(5.0 \sim 5.0)^{*, \#, \neq}$ \\
\hline & Day 30 & $0.0(0.0 \sim 0.0)$ & $3.0(3.0 \sim 4.0)^{*}, \bullet$ & $2.0(2.0 \sim 2.0)^{*, \S}$ & $3.0(3.0 \sim 3.0)^{*}, \#, \bullet$ \\
\hline
\end{tabular}

Significant difference compared to corresponding *control, ${ }^{\S}$ Cisplatin group and ${ }^{*}$ cisplatin + hAFSCs group.

Significant difference compared to intragroup ${ }^{\ddagger}$ day $4,{ }^{\dagger}$ day $7, \bullet^{\bullet}$ day 11 by Kruskal-Wallis test followed by Mann-Whitney's tests at $\mathrm{p} \leq 0.05$. Abbr.; OSOM: outer strip of outer medulla.

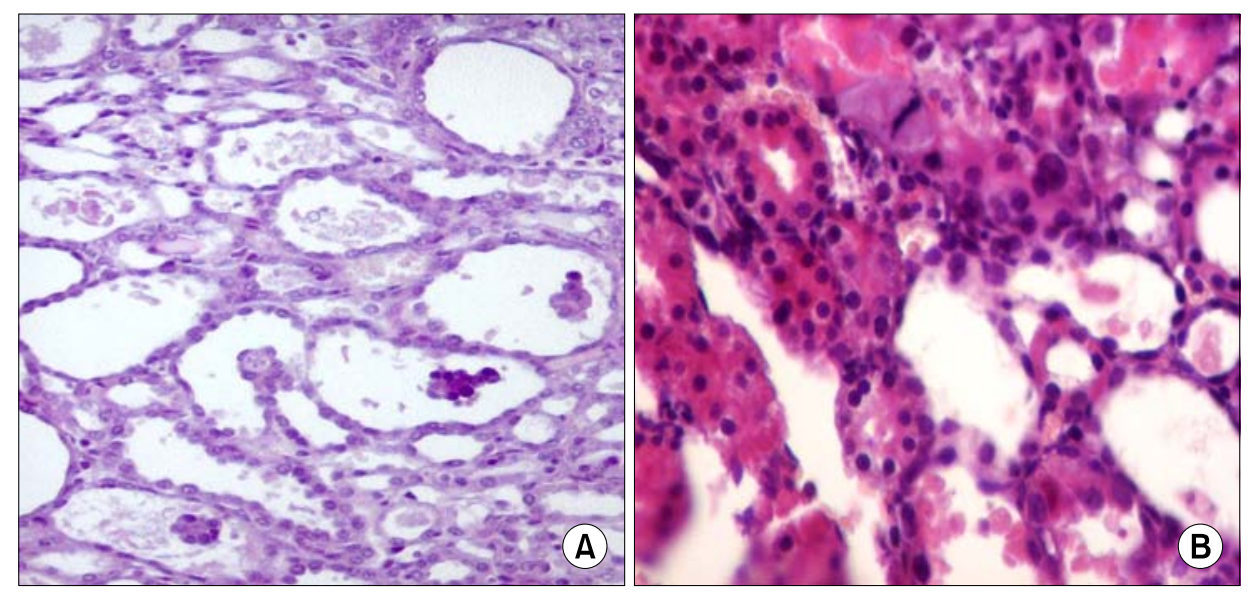

Fig. 1. Day 4: (A) Pathological changes in cisplatin injected rats (group I) at day4 shows necrotic dilated tubules in outer strip outer medulla (OSOM) where the tubules are dilated with thin denuded lining epithelium with Marked degenerative changes. It varied from tubular cell vacuolar degeneration, up to complete tubular necrosis and shedding of tubular cells $(6 \sim 10$ tubules $/ \mathrm{HPFs})(\mathrm{H} \& \mathrm{E} \times 200)$. (B) Histopathologic changes in hAFSCs-treated rats sacrificed after 4 days, OSOM shows less tubular necrosis with focal tubular dilation and occasional mitosis Mild regenerative changes were also detected in OSOM in the form of some regenerating tubules (5\%) lined by large cells with prominent nucleoli and with occasional mitotic figures. No solid sheets were detected $(\mathrm{H} \& \mathrm{E} \times 200)$.

pared to cisplatin- and culture media- injected rats at each time point (Table 3).

\section{Discussion}

The present study demonstrated that stem cells isolated from human amniotic fluid accelerate the recovery of experimental cisplatin-induced AKI. Treatment with hAFSCs significantly improved renal function, reduced oxidative stress, and increased the regenerative capacity of the kidney.
Several studies investigated the potential role of stem cells in repair of AKI. Most of these used bone marrow-derived stem cells (BMSCs) and/or in vitro expanded MSCs that were applied to different experimental models (10). De Coppi and associates (20) isolated and characterized amniotic fluid stem cells with potential to differentiate into various cell lineages. Since then, several studies provided evidence concerning their multipotency and therapeutic potential in animal models.

In the present work, hAFSCs injected IV through tail vein one day after cisplatin led to biochemical and struc- 
tural improvement of AKI. These results are in accordance to Perin et al. (21) who demonstrated the efficacy of intraparenchymally injected hAFS cells in preventing renal damage in $\mathrm{nu} / \mathrm{nu}$ mice with glycerol-induced AKI; however, in such study stem cells were given before the onset of renal damage. In addition, it was documented that in NOD/SCID mice with established cisplatin-induced AKI, hAFS cell treatment ameliorated tubular damage, limited renal function impairment, and prolonged animal lifespan (22).

In the present study, cisplatin and culture-media injected groups showed significant increase of renal tissue MDA level with significant decrease of GSH and SOD levels. These results are in agreement with previous studies that showed renal toxicity of cisplatin manifests as increased renal oxidative damage $(23,24)$. Injection of hAFSCs limited cisplatin-induced renal oxidative damage. Studies about the antioxidant action of stem cells are few; however, it was reported that adipose-derived stem cells exerted antioxidant action and protected human dermal fibroblasts from oxidant damage (25).

Here, rats injected with cisplatin and culture media developed marked degenerative changes and ATN at $4^{\text {th }}$ day post-injection (Fig. 1A). However, cisplatin-injected rats and treated with hAFSCs showed importantly less degenerative changes at the same time point (Fig. 1B). These results are in agreement with previous studies reporting that cisplatin-induced renal structural damage in animal models affects the proximal tubules specifically the S3 segment of the OSOM by acute necrosis. The severity of necrosis is dose-, concentration-, and time-dependent (26). The ability of hAFSCs to create a regenerative environment was supported by the increased regeneration score at $4^{\text {th }}$ day, the time point at which untreated and culture media treated rats exhibited higher injury score. These results are in accordance to Rota et al. who indicated that local activation of renal intracellular signaling by hAFSCs elicited antiapoptotic and proliferative responses (22).

The novelty of this study originates through combined study of the acute injury oxidative stress parameters and the morphological changes. In addition; long term 30 days follow up permitted evaluation of the activity of hAFSCs in limiting the consequent fibrosis on top of cutting short the acuteness of cisplatin-induced acute nephrotoxicity. The assessment of renal histolopathologic changes has been conducted using a new histopathology scoring system that includes different features of injury, regeneration and chronicity separately.

Injection of single dose of hAFSCs early in cisplatin-induced acute nephrotoxicity cut short the acuteness of renal injury through most probably a renoprotective paracrine antioxidant activity with consequent reduction of the developing renal fibrosis. This suggested protective non-regenerative activity of hAFSC is supported by the still absent solid sheets in the interstitium by day 4 and their appearance by day 7 and day 11 together with continuously improving biochemical parameters. Booster dose of hAFSCs may have synergistic antifibrotic activity. This

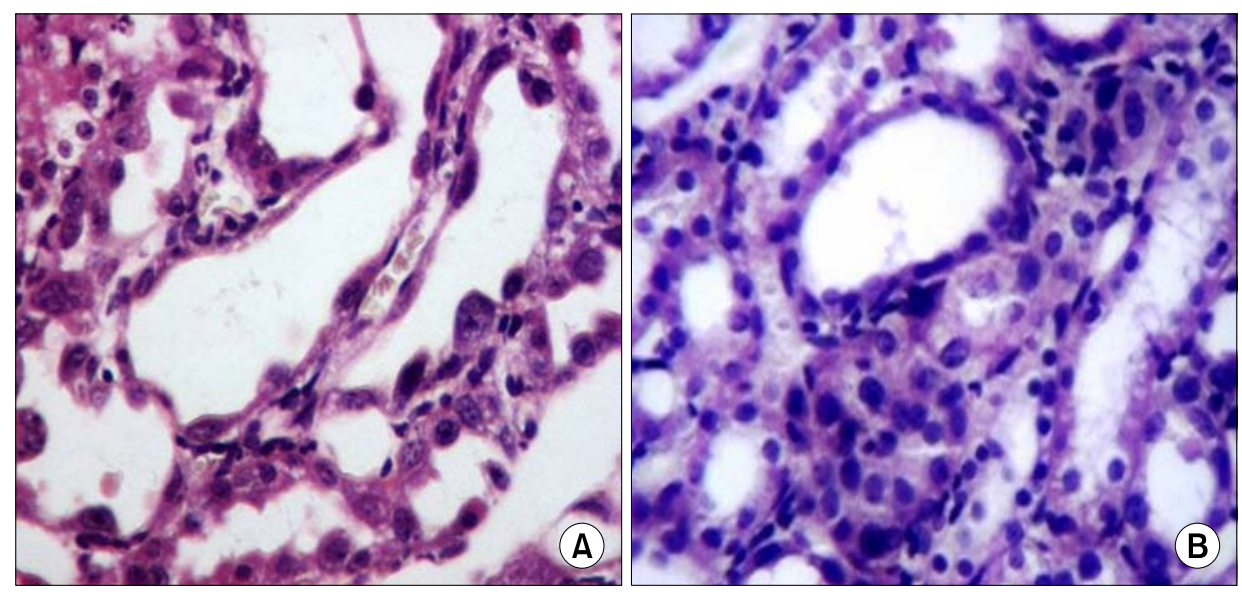

Fig. 2. Day 11: (A) kidney sections obtained from cisplatin injected rats at the $11^{\text {th }}$ day revealed that the degenerative changes varied from tubular cell vacuolar degeneration, up to complete tubular necrosis. Also there was mild interstitial round cell infiltrate. Regenerative changes were also detected and varied from tubular cell enlargement with regenerative atypia, mitosis and interstitial solid sheet formation $(\mathrm{H} \& \mathrm{E} \times 200)$. (B) Kidney sections obtained from cisplatin injected rats treated with hAFSCs via tail vein and scarified at the $11^{\text {th }}$ day revealed necrotic tubules with tubular dilatation (1 2 tubules /HPFs). Regenerative changes were detected in the form of solid sheets (3/ $10 \mathrm{HPFs})$, mitosis (1 2/10 HPFs) and presence of regenerating tubules. The interstitium was the seat of solid sheets and round cell infiltration (H\&E $\times 200)$. 
assumption could be supported by the important histopathological finding of the increasing regenerative activity at day 11 in the OSOM with excessively migrating mononuclear cells from the inner medulla (Fig. 2B). Although this study demonstrated paracrine antioxidant activity of hAFSCs; however, the exact mechanisms underlying this action are not specifically elucidated. The antioxidant potential of hAFSCs could be suggested through either secretion of soluble growth factors and cytokines with antioxidant activity as previously described (27), or augmenting endogenous antioxidant and/or regenerative cellular mechanisms (28).

Actually hAFSCs are promising target in regenerative medicine as they carry specific advantages in comparison to other stem cell types. First; hAFSCs are easy to be obtained from the amniotic fluid without ethical concerns. Second; hAFSCs cells are less liable to form tumors in vivo as they are genomically stable. Third; hAFSCs obtained during the first trimester can be reprogrammed efficiently with maintenance of pluripotency, only with the employment of a valproic acid (11).

In conclusion, hAFSCs may provide an alternative promising source of stem cells for the prevention and treatment of cisplatin-induced AKI. hAFSCs single dose early in cisplatin induced acute nephrotoxicity cut short the acuteness of renal injury with consequent reduction of the developing renal fibrosis. Boaster dose of hAFSCs may have synergistic ant fibrotic activity.

\section{Acknowledgment}

This work was supported by science and technology development fund (STDF), grant number 1061, Minister of scientific research, Egypt.

\section{Potential conflict of interest}

The authors have no conflicting financial interest.

\section{Supplementary Materials}

Supplementary data including three figure can be found with this article online at http://pdf.medrang.co.kr/paper/ pdf/IJST/IJST-09-s001.pdf.

\section{References}

1. Bellomo R, Kellum JA, Ronco C. Acute kidney injury. Lancet 2012;380:756-766

2. Bentley ML, Corwin HL, Dasta J. Drug-induced acute kidney injury in the critically ill adult: recognition and prevention strategies. Crit Care Med 2010;38(6 Suppl):S169-
S174

3. Ciarimboli G, Ludwig T, Lang D, Pavenstädt H, Koepsell H, Piechota HJ, Haier J, Jaehde U, Zisowsky J, Schlatter E. Cisplatin nephrotoxicity is critically mediated via the human organic cation transporter 2. Am J Pathol 2005; 167:1477-1484

4. Wei Q, Dong G, Franklin J, Dong Z. The pathological role of Bax in cisplatin nephrotoxicity. Kidney Int 2007;72:53-62

5. Jo SK, Cho WY, Sung SA, Kim HK, Won NH. MEK inhibitor, U0126, attenuates cisplatin-induced renal injury by decreasing inflammation and apoptosis. Kidney Int 2005; 67:458-466

6. Lee S, Moon SO, Kim W, Sung MJ, Kim DH, Kang KP, Jang YB, Lee JE, Jang KY, Lee SY, Park SK. Protective role of L-2-oxothiazolidine-4-carboxylic acid in cisplatin-induced renal injury. Nephrol Dial Transplant 2006;21:20852095

7. Ramesh G, Reeves WB. TNF-alpha mediates chemokine and cytokine expression and renal injury in cisplatin nephrotoxicity. J Clin Invest 2002;110:835-842

8. Pabla N, Dong Z. Cisplatin nephrotoxicity: mechanisms and renoprotective strategies. Kidney Int 2008;73:994-1007

9. Takaori K, Yanagita M. Kidney regeneration and stem cells. Anat Rec (Hoboken) 2014;297:129-136

10. Shokeir AA, Harraz AM, El-Din AB. Tissue engineering and stem cells: basic principles and applications in urology. Int J Urol 2010;17:964-973

11. Cananzi M, De Coppi P. CD117+ amniotic fluid stem cells: state of the art and future perspectives. Organogenesis 2012;8:77-88

12. Siegel N, Rosner M, Hanneder M, Freilinger A, Hengstschläger $M$. Human amniotic fluid stem cells: a new perspective. Amino Acids 2008;35:291-293

13. Perin L, Giuliani S, Jin D, Sedrakyan S, Carraro G, Habibian R, Warburton D, Atala A, De Filippo RE. Renal differentiation of amniotic fluid stem cells. Cell Prolif 2007;40:936-948

14. Rombouts WJ, Ploemacher RE. Primary murine MSC show highly efficient homing to the bone marrow but lose homing ability following culture. Leukemia 2003;17:160-170

15. Peister A, Mellad JA, Larson BL, Hall BM, Gibson LF, Prockop DJ. Adult stem cells from bone marrow (MSCs) isolated from different strains of inbred mice vary in surface epitopes, rates of proliferation, and differentiation potential. Blood 2004;103:1662-1668

16. van Roeyen CR, Ostendorf T, Denecke B, Bokemeyer D, Behrmann I, Strutz F, Lichenstein HS, LaRochelle WJ, Pena CE, Chaudhuri A, Floege J. Biological responses to PDGF-BB versus PDGF-DD in human mesangial cells. Kidney Int 2006;69:1393-1402

17. Saad SY, Arafah MM, Najjar TA. Effects of mycophenolate mofetil on cisplatin-induced renal dysfunction in rats. Cancer Chemother Pharmacol 2007;59:455-460

18. Ohkawa H, Ohishi N, Yagi K. Assay for lipid peroxides in animal tissues by thiobarbituric acid reaction. Anal Biochem 1979;95:351-358 
19. Ellman GL. Tissue sulfhydryl groups. Arch Biochem Biophys 1959;82:70-77

20. De Coppi P, Bartsch G Jr, Siddiqui MM, Xu T, Santos CC, Perin L, Mostoslavsky G, Serre AC, Snyder EY, Yoo JJ, Furth ME, Soker S, Atala A. Isolation of amniotic stem cell lines with potential for therapy. Nat Biotechnol 2007;25: 100-106

21. Perin L, Sedrakyan S, Giuliani S, Da Sacco S, Carraro G, Shiri L, Lemley KV, Rosol M, Wu S, Atala A, Warburton D, De Filippo RE. Protective effect of human amniotic fluid stem cells in an immunodeficient mouse model of acute tubular necrosis. PLoS One 2010;5:e9357

22. Rota C, Imberti B, Pozzobon M, Piccoli M, De Coppi P, Atala A, Gagliardini E, Xinaris C, Benedetti V, Fabricio AS, Squarcina E, Abbate M, Benigni A, Remuzzi G, Morigi M. Human amniotic fluid stem cell preconditioning improves their regenerative potential. Stem Cells Dev 2012;21:1911-1923

23. Atessahin A, Yilmaz S, Karahan I, Ceribasi AO, Karaoglu A. Effects of lycopene against cisplatin-induced nephrotoxicity and oxidative stress in rats. Toxicology 2005;212: 116-123

24. Kuhad A, Pilkhwal S, Sharma S, Tirkey N, Chopra K.
Effect of curcumin on inflammation and oxidative stress in cisplatin-induced experimental nephrotoxicity. J Agric Food Chem 2007;55:10150-10155

25. Kim WS, Park BS, Kim HK, Park JS, Kim KJ, Choi JS, Chung SJ, Kim DD, Sung JH. Evidence supporting antioxidant action of adipose-derived stem cells: protection of human dermal fibroblasts from oxidative stress. J Dermatol Sci 2008;49:133-142

26. Vickers AE, Rose $\mathrm{K}$, Fisher R, Saulnier M, Sahota P, Bentley P. Kidney slices of human and rat to characterize cisplatin-induced injury on cellular pathways and morphology. Toxicol Pathol 2004;32:577-590

27. Imberti B, Morigi M, Tomasoni S, Rota C, Corna D, Longaretti L, Rottoli D, Valsecchi F, Benigni A, Wang J, Abbate M, Zoja C, Remuzzi G. Insulin-like growth factor-1 sustains stem cell mediated renal repair. J Am Soc Nephrol 2007;18:2921-2928

28. Morigi M, Rota C, Montemurro T, Montelatici E, Lo Cicero V, Imberti B, Abbate M, Zoja C, Cassis P, Longaretti L, Rebulla P, Introna M, Capelli C, Benigni A, Remuzzi G, Lazzari L. Life-sparing effect of human cord blood-mesenchymal stem cells in experimental acute kidney injury. Stem Cells 2010;28:513-522 